\title{
WAYS OF SIGNAL TRANSMISSION AND PHYSIOLOGICAL ROLE OF ELECTRICAL POTENTIALS IN PLANTS
}

\author{
HALINA DZIUBIŃSKA \\ Department of Biophysics, Institute of Biology, Maria Curie-Skłodowska University \\ Akademicka 19, 20-033 Lublin, Poland \\ e-mail: dziub@biotop.umcs.lublin
}

(Received: February 21, 2003. Accepted: July 28, 2003)

\begin{abstract}
Plants are subject to stimuli from the environment on which they strongly depend and in contrast to animals, they are unable to escape harmful influences. Therefore, being able to receive stimuli they have developed adequate responses to them. Such a reaction can occur in the area of a stimulus action or cover the whole plant or its parts. In the latter case, it is a systemic reaction. The plant reaction is expressed by various intensity, rate and kind of response. It is interesting to know the character of the signal informing about a stimulus, the routes of its propagation and the transmission mechanism. Three conceptions of excitation are distinguished: 1) propagation of chemical agents formed at the site of a stimulus action with the flow of the phloem sap or through the atmosphere (in the case of volatile substances) to other plant parts, 2) a very fast transmission by the xylem in the wave of hydraulic pressure formed after a plant damage. From combining the „hydraulic” and „chemical” hypothesis a conception of hydraulic dispersion has been formulated which assumes that chemical substances synthetized after an injury can be transferred very fast with the wave of hydraulic pressure changes in the whole plant, 3) a stimulus evokes the action potential (AP), and its transmission along the whole plant, plant organ or specialized tissue, by local circuits from cell to cell. Strong, damaging stimuli can evoke variation potentials (VPs), the character of which differs from APs. It is postulated that transmission of VP occurs by a hydraulic dispersion and electrical changes seem to be secondary phenomena.
\end{abstract}

KEY WORDS: action potential, variation potential, signal transmission, systemic response.

\section{SIGNALS TRANSMISSION IN THE CHEMICAL WAY}

The theory assuming the release of a chemical substance from a damaged cell was published by Ricca (1926). From the autor's name the non-defined substance produced by a plant wounding was called „Ricca's factor”. Since that time many chemical substances of different character have been ascribed to participation in signal transmission and systemic responses.

The proteinase inhibitor-inducting factor (PIIF) is a substance affecting the expression of some genes responsible for synthesis and accumulation of proteinase inhibitors (PIs) in tomato leaves which were directly damaged and those being distant (Green and Ryan 1973; Ryan 1974). Proteinase inhibitor (PI) suppressing metabolism of proteins leads to their accumulation by which they become defensive for the plant, and harmful for pathogenes, and viruses. At present, many elicitors are attributed to the role of PIIF in induction of gene expression in the directly damaged area as well as in distant place not subject to the action of the stress factor.
Induction of gene expression as well as synthesis of defence compounds and changes in metabolism occur generally immediately after stimulation, therefore high-molecular, immobile chemical compounds cannot play a signaling role at long distances. However, they can be one of the first links in the signaling chain or be responsible for the occurrence of local responses (Green and Ryan 1973; Ryan 1974).

To these compounds belong oligosaccharins such as oligogalacturonids, oligoglucan, oligochitine, oligochitosan (Wildon et al. 1989; Creelman and Mullet 1997; Ebel and Mithöfer 1998). In damaged leaves of Arabidopsis thaliana oligosaccharins induce expression of genes only in the place of wounding and are recognized as the first link in the chain of changes following the damage (Rojo et al. 1999). Also fatty acids and their derivatives are signaling factors in Arabidopsis (Farmer et al. 1998), as well as some oligopeptides are included into systemic postdamage response in potatoes and tomatoes (Narváez-Vásquez et al. 1995).

Systemin, which induces synthesis of proteinase inhibitors in damaged and distant undamaged leaves, belongs to mobile factors playing a role in a response to wounding 
(Sticher et al. 1997; Howe and Ryan 1999). ${ }^{14}$ C-systemin applied to the damaged site of a tomato leaf was found to spread in the whole leaf within 30 min (Narváez-Vásquez et al. 1995), and after 5 hours the whole plant showed the presence of the labelled systemin. Its transport takes place in the phloem and in this way, as systemic signal, reaches distant plant parts in which it activates genes of proteinase inhibitors. The same way of transmission is proposed in the case of other polypeptides (elicitin, cryptogein), which can be recognized as signal substances participating in systemic responses of the plant to damages (Fisher 1992; Ebel and Mithöfer 1998).

Salicylic acid (SA) belongs also to mobile plant hormones. It participates in systemic acquired resistance (SAR) in response to infections with pathogens. Infection of tobacco or cucumber leaves causes a considerable increase of SA concentration in the phloem sap not only in damaged place but also in uninfected, distant tissues (Dempsey et al. 1999). SA transport, however, is too slow to consider that SA plays the role of a direct signal inducing systemic resistance to stress. Induction of systemic resistance occurs only at high SA concentrations in ultimately infected leaves (Ryals et al. 1996; Birkenmeier and Ryan 1998; Ebel and Mithöfer 1998) therefore its main role is ascribed to local responses.

Biochemical and molecular studies of defense reactions of plants to the infection by pathogens and viruses allowed identification of other signaling substances taking part in defence against stress events: jasmonic acid (JA), methyl ester of jasmonic acid (Me-JA), abscisic acid and ethylene were mentioned (León et al. 2001).

Jasmonic acid solution administered to a leaf or to the soil in which tomato seedlings (Lycopersicon esculentum) were growing induced expression of genes of proteinase inhibitors in the whole plant (Farmer et al. 1992). Isolation of a single tomato leaf from the rest of the plant by covering it in a glass chamber and application of volatile Me-JA also induced synthesis of proteinase inhibitors. Accumulation of proteinase inhibitor was the highest in the leaf kept in Me-JA atmosphere, while in the neighbour leaf the amount of proteinases inhibitor was twice smaller. In the plants standing beside the induction of proteins synthesis was not observed. There are reports that the above mentioned signaling volatile compounds (Me-JA and ethylene) released after leaf infection enter to atmosphere and can induce defence reactions against pathogens in other parts of the same plant or in other plants (Enyedi et al. 1992; Koda 1997; Baldwin and Preston 1999). This is another probable way of signal transmission. Mechanical damage of a leaf induces identical effects as the mentioned jasmonic acid and its ester. Expression of genes induced by jasmonates requires cooperation with other hormones, e.g. ethylene or abscisic acid (Wasternack and Parthier 1997; Penninckx et al. 1998; Glazebrook 1999; Wang et al. 2002).

The most effective chemical compound carrying information about stress could be ethylene because of its spreading ability. Ethylene as a volatile substance spreads through intercellular spaces and can penetrate the whole plant in a short time. Plant tissue damage causes increased ethylene production. In damaged pea leaves Phaseolus vulgaris defence enzymes such as chitinase, gluconase are accumulated (Mauch et al. 1992). However, the participation of ethylene as a direct signal inducing expression of genes is not unambiguous. The role of ethylene in systemic resistance of plants can consist in an increase of tissue sensitivity to the action of other factors, e.g. SA or jasmonates (Lawton et al. 1994).

The main transmission route of chemical compounds participating in signaling, besides volatile substances, is phloem (Fisher et al. 1992; Ishiwatari et al. 1995). The important feature of the phloem transmission of the compounds playing a role in signaling is that it can be directed both basi- and acropetally.

On the other hand, the xylem tissue, is attributed to transport of chemical signals by the so-called hydraulic dispersion. The essence of this mechanism is an interaction between two consequences of plant tissue damage: release of PIs inducing factors, and releasing of the hydraulic signal transporting the induction factors at high speed over a long distance (Malone et al. 1994; Malone and Alarcon 1995). The hydraulic signals are necessary for transmission of systemic information, but insufficient. Induction of PIs in distant plant parts takes place as early as $10 \mathrm{~min}$ after the wounding, only when both the inducing substance and the hydraulic signal appear. Administration of the substance of PIIF character, e.g. oligosaccharides onto the leaf blade without incising does not bring any effect itself (Malone et al. 1994). The experiments carried out by Rhodes et al. (1999) on tomato seedlings resulted in a similar conclusion. Cotyledon damage under a droplet of luciferine dye caused the dye penetrated into the xylem and moved with its sap along the petiole to the leaf. Luciferine distribution in leaves depended on which of the cotyledons was damaged. Examination of the connections between stimulated cotyledons and leaves pointed to their connection through xylem vessels. The stimuli were accompanied by systemic induction of proteinase inhibitors. PI activities were in accord with the dye distribution and the network of xylem vessels. Such results indicated the appearance of some chemical factors after damage, which were able to induce reactions. These substances moved along xylem, because destruction of living tissue by steam did not inhibit PI induction. Strong damages caused a higher PI activity which, as suggested by authors, was connected with penetration from damaged cells into xylem of a larger amount of the cell sap containing a considerable amount of inducing substances. Large amounts of the sap passed not only into xylem but also into phloem, because the level of PI should be lower, assuming its distribution only by xylem. Transport of the substance inducing PI, formed after delicate incisions, undoubtly take place by the phloem because PIIF identified by carboxyfluorescein was present only in this bundle.

\section{HYDRODYNAMIC PROPAGATION OF EXCITATION}

Hydraulic pressure wave spreading by xylem tissue can be another way of signal transmission. Mulhern et al. (1981) studied electrical changes occurring in the leaf petiole of geranium after incision of the leaf blade. Electrical potential changes were recorded already $10 \mathrm{~ms}$ after leaf damage. It is unlikely that any substance could cover in such a short time a distance of $50 \mathrm{~mm}$ from the place of damage to the measurement electrode. The rate $\left(5 \mathrm{~m} \mathrm{~s}^{-1}\right)$ and ability of the signals to pass through the cooled tissue exc- 
lude participation of action potential (AP) in signal transmission after injury. Attention was thus directed to xylem tissue and the sap present in it, which is under negative hydrostatic pressure. Disruption of the vessel continuity due to injury causes a rapid increase in the xylem sap flow rate tending to equalize the pressure with the atmospheric one. This rapid flow can bring about flows of ions in the adjacent cells, and in consequence, variation potential (VP) in distant places of the plant (Malone and Stanković 1991; Malone 1992). Recently, this conception was developed and found a broader experimental support (Stanković et al. 1997). Local scorching of a tomato leaf causes a fast increase and then a long-lasting inhibition of elongation of the petiole (Stanković and Davies 1998). This damage is accompanied by VP. Electrical changes are preceded by passing a hydraulic pressure wave through xylem, evoked by leaf damage. Application of external pressure mimicking the damage induces a comparable electrical response. It is suggested that the wave of hydraulic pressure evoked by scorching passes by xylem and activates mechano-sensitive ion channels or pumps in membranes of living cells adhering to the xylem. Flowing ions depolarize the membrane, which external electrodes register as VP. VP in turn precedes systemic plant responses in distant tissue (Stanković and Davies 1996; Davies et al. 1997; Stanković and Davies 1998). The above conception has also served to explain the phenomena appearing after scorching leaves in the shoot of Vitis vinifera. Such stimulus induces formation of electrical potential changes of VP character (Mancuso 1999). Electrodes attached to the stem recorded a potential change, the amplitude of which as well as the propagation rate decreased with the distance from the scorching place. At the same time the shoot diameter showed a transient increase. These two phenomena, i.e. variation potential and change of the shoot diameter did not occur simultaneously. VP appeared when the shoot diameter reached its maximum, but changes in the shoot diameter never accompanied AP generation. Hence, it can be concluded that VP was a response to a hydraulic wave propagated by xylem. It is further confirmed by an experiment, in which destruction of living tissues in the petiole at a length of $2.5 \mathrm{~cm}$ totally eliminated AP appearance behind a steam block, but it was not an obstacle for VP (Mancuso 1999).

\section{PROPAGATION ROUTES OF ACTION AND VARIATION POTENTIALS IN PLANTS}

Natural stimuli (change of light or temperature) coming from the environment, damaging stimuli (scorching, incision) and nondamaging ones (electrical and mechanical stimuli, illumination) induce measurable changes of electrical potential in plants. Those induced by damaging stimuli depend on their strength, cease with the distance from the stimulation place, and have variable shapes. In plant electrophysiology, they have been called variation potentials. After non-damaging stimuli, APs appear. APs are characterized by a constant amplitude, constant propagation rate and a regular shape. They fulfil classical electrophysiological laws: the all-or-none law, strength-duration relationship, and the dependence of refractory periods on the stimulus strength (Paszewski and Zawadzki 1974, 1976; Dziubińska et al. 1983; Zawadzki et al. 1995).
The main role in generation and propagation of AP is played by the plasmalemma membrane. Action potentials were recorded in unicellular algae Acetabularia, which is excitated as a whole (Gradmann 1976). In multicellular algae consisting of giant internodal cells connected by small nodal cells, e.g. Chara braunii, excitation propagates mainly along internodal cells. Cytoplasmic connections between internodal cells and nodal cells do not guarantee AP propagation, though it occurs occasionally (Sibaoka and Tabata 1981). On the other hand, cytoplasmic connections of cells in fungal mycelium allow propagation of potential changes over the whole mycelium. Electrical, chemical or mechanical stimulation of the fungi Pleurotus ostreatus and Armillaria bulbosa evokes a series of APs propagating in the mycelium (Olsson and Hansson 1995).

Electrical, mechanical and light stimuli induce generation of AP and its spreading in the whole thallus of the liverwort Conocephalum conicum (Paszewski et al. 1982; Dziubińska et al. 1983; Zawadzki and Trębacz 1985; Trębacz et al. 1989). Liverworts belong evolutionary to the oldest land plants, and their thalli are characterized by an uncomplicated structure. In response to stimulation Conocephalum generates AP or series of APs of $80-130 \mathrm{mV}$ amplitudes. AP propagates from the stimulation place in all directions, covering gradually the whole thallus and rhizoids. Similar results were obtained by Sinyukhin (1973), studying gametophytes of the moss Bryum pseudotriquetrum. Short-lasting illumination of the gametophyte induces AP formation, which also propagates in the whole plant.

APs are generated and propagated by traps of some carnivorous plants. The plant in which APs were recorded for the first time was the carnivorous Venus flytrap Dionaea muscipula (Burdon-Sanderson 1882). The active traps of Dionaea and Aldrovanda are built of excitable cells (Sibaoka 1966; Iijima and Sibaoka 1981, 1982; Hodick and Sievers 1988). The excitable cells have identical magnitude of resting potential $(-110 \mathrm{mV})$ and generate APs of 110-150 $\mathrm{mV}$ amplitudes. The propagation rate of AP in both species approximates $10 \mathrm{~cm} \mathrm{~s}^{-1}$. All the cells in the trap can participate in AP transmission between the receptor (sensory hair) and effectors (cells in the motor zone). A fast AP transmission by the trap is guaranteed by numerous plasmodesmata located between the cells of the sensory hair and those of the trap (Iijima and Sibaoka 1982).

Sundew (Drosera) possesses a passive catching device. Cells of sensory hairs generate AP, which propagates basipetally twice as fast as acropetally $\left(1.0 \mathrm{~cm} \mathrm{~s}^{-1}\right.$ and $0.5 \mathrm{~cm} \mathrm{~s}^{-1}$, respectively). All cells of the sensory hair are excitable, but it is possible that the longitudal internal cells of the hair participate mainly in the conduction of AP. The terminal walls of these cells are joined by numerous plasmodesmata (Williams and Pickard 1972; Williams and Spanswick 1976).

The propagation routes of excitation were studied in other plants exhibiting fast movements, e.g. in Mimosa. The researchers, attention was directed to vascular bundles as conduction routes, similar to nerves in animals. Bose (1925) called them even plant ,nerves”. He inserted a capillary connected with a galvanometer into the petiole of Mimosa at different depths. Only on capillary contact with phloem the galvanometer showed reaction. Layers of cortex, xylem and pith did not give this characteristic reaction. 
By this method he found that propagated excitation (evoked by mechanical or thermal stimulus) showed two maxima - one at the external, the other at the internal side of xylem. This resulted in finding that AP is propagated in the petiole of Mimosa leaf along two phloem routes separated by the xylem.

Using the Bose's method, Sibaoka (1954) confirmed that conduction of excitation in the Mimosa petiole takes place by two rows of elongated cells of the phloem tissue. At the same time he observed that stimulation could spread transversely because excitable elements are not sufficiently isolated one from another. Only in the case when excitation is propagated transversely in the Mimosa petiole it can be propagated longwise at considerable distances. Thus excitation transmission is based on cooperation of many cells. Applying microelectrode technique it was possible to determine the kind of tissues, which are routes of AP propagation. These proved to be phloem and elongated cells of protoxylem (Sibaoka 1962, 1966).

Studies with ${ }^{14} \mathrm{C}$ labelled acrylamide (Kalinin et al. 1970), application of blocks (surgical and chemical) (Kalinin et al. 1970), microelectrodes (Eschrich et al. 1988) and studies of the electrochemical gradient of ions in conducting boundless (Opritov and Retivin 1982; Retivin and Opritov 1986) pointed to phloem cells as the most predestinated to generate and transmit excitation.

Fromm and Bauer (1994), applying cut off aphid stylets, inserted through them microelectrodes precisely into sieve tubes of Zea mays and Mimosa pudica (Fromm and Eschrich 1988b). Examination of transmission routes of APs by this method allowed them to find that transmission of bioelectrical potentials takes place along the symplasmic route of phloem, though it does not exclude the participation of other plant tissues. Partial surgical exposure of a very short section of the bundles did not block AP transmission either in front or behind the block. Thus, AP is transmitted by the bundles over long distances, but locally by other tissues. The former transmission type is much faster than that occurring through mesophyle cells.

Rhodes et al. (1996) also considered phloem tissue as the main route of excitation transmission. They studied the propagation route of electrical signal mediating a local damage with the systemic response appearing in tomato leaves. Incision of the petiole surface allowed insertion of microelectrodes into cells of various types, which were identified by ionophoretic introduction of a fluorescence dye (Lucypherin Yellow) at the end of the experiment. No significant differences in values of resting potentials were recorded in various cells, but depolarization recorded after stimulation had the highest amplitude $(80 \mathrm{mV})$ in sieve or companion cells and was approx. 3 times higher in comparison with other cells of the petiole. The shape, amplitude, and duration of transient depolarization pointed to AP. Sieve elements and companion cells are closely connected symplasmically and isolated from cells of other kinds, which was demonstrated by lack of dye flow to cells surrounding them. The presence of pores in sieve elements provides continuity of membranes of low resistance over a long distance. Moreover, symplasmic isolation from other tissues makes the sieve tubes an ideal route of excitation propagation (Wildon et al. 1992; Rhodes et al. 1996). Lack of propagating electrical signals evoked by weak damage stimuli made researchers look for other transmission routes. Therefore, in their later paper Rhodes et al. (1999) did not attribute electrical potentials to their sole participation in response to stress. In the light of new evidences, they recognized priority of chemical factors formed at place of wounding and propagated by xylem. Propagation of these factors is also possible by phloem.

In the paper of Paszewski and Zawadzki (1976b), a ring of tissues outside xylem, including phloem, was removed from lupine stem at a length of $5-10 \mathrm{~mm}$ to examine the route of excitation transmission. After electrical or a weak thermal stimulation AP appeared, which was recorded by an electrode attached to the stem in front of block. Electrodes located behind the block did not record any change, which would account for the participation in excitation transmission of the tissues located outside xylem, including phloem tissue. After a strong stem scorching, AP appeared in the form of a sharp peak followed by VP with the range and the amplitude proportional to the stimulus strength. While AP stopped at the block, VP was transmitted and recorded by electrodes located behind the block. This account for participation also of other tissues in VP transmission. If VP had sufficiently high amplitude it evoked AP behind the block.

Events of this kind were also observed by Zawadzki and Trębacz (1982). By tightening a nylon threat around the lupine stem its external layers were destroyed. After a strong tightening, which destroyed cell layers including phloem, electrically triggered AP did not pass through the block. Behind the block only potential changes of electrotonic character were recorded. On weaker tightening AP passed through the block, but its amplitude was twice lower than that recorded in front of the block, although its transmission rate did not change. Some distance behind the block development of AP of full amplitude was sometimes observed, it could propagate in two directions covering cells, which were not excited before. In this experiments participation of cells of primary cortex including phloem in AP propagation was shown.

AP propagation in Lupinus stem was studied by Hejnowicz et al. (1986), using an AC amplifier. The recorded signals were interpreted as originating from rows of excitable cells. According to the authors, AP recorded by the traditional method (DC amplifier) resulted from averaging of signals from excitable cells with involvement of volume conductance of the remaining tissues.

Zawadzki et al. (1995) registered spontaneous action potentials (SAPs) in sunflower, whose appearance in different plant regions was quite nontypical. From multichannel extracellular recording SAPs were found to appear locally, covering larger or smaller plant region and then they disappear. It is possible that SAPs propagate along limited rows of excitable cells. This has been confirmed by studies of APs and VPs evoked in Helianthus annuus. The plants, which were stimulated by electrical stimuli, generated AP which, propagating, involved the whole plant except leaves. Another stimulation type, i.e. leaf scorching evoked generation of variation potentials whose transmission differed distinctly from AP. Electrodes being at the same height and inserted at a depth of approx. $1 \mathrm{~mm}$ on various stem sides recorded VP only on the side of conducting bundles lying in the leaf trace of the stimulated leaf. On the opposite stem side no potential changes were recorded, or they occurred with a low amplitude (Dziubińska et al. 2001). 
VPs evoked by leaf scorching often entered leaves at lower levels. Similarly, stimulation of one tomato leaf with electrical stimulus induced AP, whereas after scorching VP was observed. Stimulations of such a different character induced the same events in distant leaves (Davies et al. 1997). The authors recognize two bioelectric carriers of information upon wounding: APs transmitted by the floem or the hydraulic pressure wave propagating by the xylem inducing local changes of membrane potential in adhering living cells, which is recorded as VP. They also take into account participation in signal transmission of chemical compounds formed after wounding and translocated by the xylem or the phloem.

The results obtained on Vicia faba also suggest that VP propagation takes place by vessels (Roblin and Bonnemain 1985). Conduction of VPs takes place when the continuity of conducting bundles between the stimulated leaf is maintained. Transmission of excitation occurs also transversely because VPs were recorded in bundles isolated from the stimulated leaf. Thus cells of other tissues participate in VP transmission across $V$. faba stem. The authors also suggest coexistence of VP transmission based on ion currents as well as on transport of a stimulating substance formed as a result of plant damage. Local stem cooling to $1^{\circ} \mathrm{C}$ inhibited bioelectrical response in this area, but it did not stop propagation of the stimulating substance, which induced VP behind the cooled region.

Signals evoked by a plant damage propagate systemically, reaching all plant tissues, and run distinctly along definite routes. In the latter case some regions of the plant organism are beyond reach of electrical signals. Detailed knowledge of propagation ways of these signals will allow accurate interpretation of results concerning plant responses to stimuli.

\section{PHYSIOLOGICAL ROLE OF ELECTRICAL ACTIVITY IN PLANTS}

Recognized existence of electrical responses (of AP and VP character) in plants has resulted in attempts at connecting electrical changes appearing after stimuli with changes in physiological processes. It is important to monitor the two phenomena simultaneously, which allows precise estimation of temporal sequences of these events.

Sensitive and carnivorous plants have become objects of studies as they exhibit motor properties.

Mimosa pudica reacts to the touch by generating AP and subsequent leaflets folding and lowering the whole leaf. In $0.1 \mathrm{~s}$ after AP passing, a large amount of ions together with water flows out from the pulvinus. The result of it is decrease of turgor by motor cells and a fast leaf movement. An identical mechanism of leaflets folding occurs in Biophytum (Sibaoka 1973). Local chilling of the edge of the $M i$ mosa pudica petiole induces AP. The result of keeping terminal leaflets in ${ }^{14} \mathrm{CO}_{2}$ was that after 3-6 h labelled photoassymilates appeared in the phloem. Localization of the labelled photoassimilates was studied by the autoradiographic method before and after stimulation, i.e. before and after AP passage. The microradiograms showed that labelled assimilates of unstimulated plant were located only in phloem. After stimulation, when AP reached the pulvinus, membrane permeability undoubtedly increased and a relea- se of labelled photoassymilates from pulvinus cells to apoplast took place (Fromm and Eschrich 1988a; Fromm 1991). Sudden increase of the concentration of assimilates in apoplast causes water efflux from cells, mainly from motor cells of the pulvinus to apoplast, and in consequence decrease of their turgor and leaf folding. The mechanism of rhythmical movements of Desmodium motorium leaflets also consists in reversible changes of turgor pressure in motor cells of the pulvinus (Antkowiak and Engelmann 1995). Pressure changes and leaflets movements appeared following AP. Oscillations of $\mathrm{K}^{+}$activity measured in the pulvinus apoplast were correlated with changes of the membrane potential. Apoplastic $\mathrm{K}^{+}$activity increased when the membrane of pulvinus cells depolarized and leaflets moved downwards. Upward leaflet movement was accompanied by $\mathrm{K}^{+}$concentration decrease in apoplast.

APs appearing in carnivorous plants are important elements of the uptake mechanism of nitrogen rich compounds. The fly-trap Dionaea muscipula has a leaf-trap, which closes along the central nerve. The trap edges are supplied with thorny processes, which make the impression of a trap. On the leaf surface Dionaea possesses glands being an attraction for insects, as well as multicellular sensory hairs. Bending such a hair by an insect evokes a graded electrical response in sensory cells within hairs depending on the intensity and a rate of bending (Sibaoka 1969). After exceeding a certain value of depolarization, AP appears which at a rate of $10 \mathrm{~cm} \mathrm{~min}^{-1}$ propagates all over the trap. The first stimulation does not make the trap close, but it is ,memorized". If within $20 \mathrm{~s}$ the second stimulation takes place the AP propagates over the trap at approx. 3 times higher rate and the trap is closed. The motor cells are supposed to act on the same principle as in Mimosa (Sibaoka 1969; Jacobson 1974; Sibaoka 1979). Basing on the hypothesis of acid growth, a different mechanism was proposed by Williams and Bennet (1982). AP evoked after stimulation causes a fast $\mathrm{H}^{+}$efflux into the cell walls of the lower side of the trap, in the area of the main nerve. Protons cause cell wall loosening, which leads to fast water absorption by cells and their volume increase. Asymmetrical volume change of the lower and upper trap sides causes its closing.

The physiological significance of AP was shown also in other carnivorous plants, e.g. Aldrovanda, Drosera (Sibaoka 1979; Iijima and Sibaoka 1981, 1982, 1983, 1985). In these plants the mechanism of stimulus perception by the hair receptor cells, excitation transmission, trap closure on the basis of turgor decrease by motor cells are similar to that in Dionaea.

Water loss by sieve cells that causes leaf movement disturbs phloem transport. Electrical stimulation of the Phaseolus vulgaris stem and stimulation of Zea mays leaf with thermal shock stops (totally or partially) the translocation of the phloem sap (Fromm and Bauer 1994; Pickard and Minchin 1990, 1992). Transport inhibition is the result of opening of ion channels in the plasmalemma and an efflux of $\mathrm{K}^{+}$, and $\mathrm{Cl}^{-}$ions together with water from phloem cells into apoplast. These ions together with $\mathrm{Ca}^{2+}$ are the main ions taking part in AP generation.

APs participate in the first stage of fertilization of the moss Bryum pseudotriquetrum and the fern Asplenium trichomanes, and thereby in the process of reproduction. A short-lasting illumination of the gametophyte of these 
plants induced electrical changes propagating over the whole thallus (Sinuykhin 1973). Within 2 s after passing of depolarization wave water efflux (guttation) so indispensable in fertilization of these plants begins. AP regulates also other aspect of plant preparation for fertilization as is the case in Lilium martagon, Lilium longiflorum and Incarvillea grandiflora (Sinuykhin and Britikov 1967; Spanjers 1981). In Incarvillea, stimulation of the stigma by an insect induces AP, which, propagating at a rate of $1.8 \mathrm{~cm} \mathrm{~s}^{-1}$ reaches the place of connection of the bilobal stigma. The stigma closes within 6-10 s. AP does not pass below the stigma. If mechanical stimulation is not accompanied by pollination, the stigma opens again after several minutes. In case the deposited pollen begins to germinate on the stigma, chemical processes lead to depolarization of the stigma cells and the induction of subsequent AP, which, at a higher rate than the preceding, propagates along the style reaching the ovary after several dozens of seconds. Metabolic processes are activated in the ovary, respiration increase is observed. In this way the ovary is preparing for acceptance of the pollen-tube with sperm cells and for fertilization. Such two-stage AP transmission is very advantageous for Incarvillea, because it eliminates accidental mechanical stimulation of the stigma for instance by insects which have not brought any pollen. The stigma of Lilium martagon does not show motor properties as Incarvillea, but germinating pollen induces similar electrical and metabolic reaction as in Incarvillea. A mechanism of protection against fertilization with improper pollen was found in $\mathrm{Li}$ lium (Spanjers 1981). Electrical potentials generated after depositing an improper pollen on the stigma differed from those induced by a proper pollen. Similar preparation of the ovary for acceptance of the male cell was demonstrated in Hibiscus (Fromm et al. 1995). Stimulation of the plant stigma with a compatible pollen induced series of APs, which are propagated along the style to the ovary. The ovary response (after 3-5 min since stimulation) was in the form of increased respiration rate by approx. $12 \%$, levels of ATP, and sugars (glucose, fructose and saccharose). Scorching of Hibiscus stigma induced electrical response differing from AP. It was shown that different physiological and non-physiological stimuli applied to Hibiscus stigma induced specific electrical responses, which, propagating along the pistil, „carry” information to the ovary. Depending on the kind of the signal the ovary is preparing for fertilization, changing its metabolism or not. The biochemical responses of the ovary to pollination are so fast that only APs can take part in signal transmission. Preparation for plant fertilization based on generation of electrical potentials can be a phenomenon commonly occurring. It is even supposed that AP but not florigen (flowering hormone) is responsible for plant flowering (Davies 1987).

Passing AP wave influences the intensity of gas exchange in angiosperm plants: Cucurbita pepo, Phaseolus vulgaris (Gunar and Sinuykhin 1963; Sinuykhin and Gorchakov 1968), Lycopersicon esculentum (Van Sambeek and Pickard 1976), Salix viminalis (Fromm and Eschrich 1993), Vicia faba (Filek and Kościelniak 1997), Zea mays (Fromm and Fei 1998). In evolutionary distant plants, belonging to the oldest land plants as the liverwort Conocephalum, electrical or mechanical stimulation (incision of the thallus edge) induces AP or VP, and in several seconds later the respiration intensity increases by up to $100 \%$
(Dziubińska et al. 1989). In the case of APs series, the respiration increase is correlated with subsequently appearing APs. In unexcitable thalli stimulation does not induce either AP or VP and does not cause a change in respiration rate, either. Such a fast plant reaction to stress can appear only when a fast propagating signal is involved. In this case only electrical potentials satisfy the condition. They can play an informative role and coordinate physiological processes in the whole plant regardless of the place where a stimulus acts.

Fast electrical signalization guarantees communication of the whole mycelium in the fungi Pleurotus ostreatus and Armillaria bulbosa (Olsson and Hansson 1995) carrying information about damages, pathogens and locally changing conditions. Similarly, the electrical change appearing in several seconds after illumination by red light in a caulonemal filament of the moss Physcomitrella patens precedes the initial stage of gametophyte development (Ermolayeva et al. 1996).

Application of abscisic acid to willow roots induces acropetally propagating APs. After reaching leaves (in 2-3 s) they cause instantaneous closing of stomata (Fromm 1991). The ionic mechanism of AP and the closing mechanism of stomata show a great similarity (Schroeder 1992).

Preparation of tissues for defence against various stresses, among other things against effects of low temperature, belongs to the physiological phenomena controlled by AP (Retivin et al. 1997; Pyatygin et al. 1999). Moreover, AP causes a reduction of the growth rate of stem internodes in Luffa cylindrica (Shiina and Tazawa 1986), inhibits water uptake and stem growth of Helianthus annuus (Davies et al. 1991). Chemical stimuli induce changes of electrical potential, which in turn stimulate growth of etiolated seedlings and affect nutation and phototropic movements (Spalding and Cosgrove 1993). Touch and gravitation are stimuli, which affect growth of Arabidopsis seedlings, and APs, besides other candidates, are recognized as factors mediating between stimulus and reaction (Fasano 2002).

In response to changes occurring in the environment plant cells are able to synthetize various protective substances. Addition to the soil, in which 3-week-old soybean seedlings (Glycine max (L) Merrill) grow, of pentachlorofenol (PCP), carbonyl cyanide 4-trifluoromethoxyphenylhydrazone (FCCP), carbonyl cyanide 3-chlorophenylhydrazone (CCCP) solution induces AP formation, which propagates along the stem at a rate of $30 \mathrm{~m} \mathrm{~s}^{-1}$ (Volkov et al. 2000; Shvetsova at al. 2001; Volkov and Mwesigwa 2001; Labady et al. 2002). Such fast AP transmission seems to be necessary for the plant to react quickly to the presence of extremely harmful chemical compounds in the medium, by producing phytoalexins or stress proteins. Neverthless it should be stressed that these are the first reports presenting such a fast AP transmission. As yet the highest rate of AP transmission (7.0-25.0 $\left.\mathrm{cm} \mathrm{s}^{-1}\right)$ has been recorded in carnivorous plants (Sibaoka 1966, 1969; Iijima and Sibaoka 1982).

Furthermore, measurements of APs and VPs can be used as environmental biosensors for studying the influence of external stimuli on plants, i.e. acid rain (Shvetsova et al. 2002).

Participation of AP in regulation of peroxidase activity in Conocephalum thallus has been shown (Dziubińska et al. 1999). After local incision of thallus APs were generated. 
Soon after that a doubling (approx.) of peroxidase activity was recorded. AP absence despite stimulation or appearance of only local responses of small amplitudes had no influence on peroxidases activity. The results of these studies distinctly point to participation of APs in formation of systemic response to stress.

Owing to application of rapidly developing techniques of molecular biology attempts could be made to determine stress influence on gene expression. Mechanical injury of tomato leaf results in expression of gene pin2 encoding protective substance - proteinase inhibitor (Stanković and Davies 1996; Vian et al. 1996; Davies at al. 1997; Stanković and Davies 1997, 1998; Herde et al. 1999) as well as calmodulin (cal) encoding gene (Davies et al. 1997). The activity of pin2 is correlated with the electrical signal, which appears after injury and passes along the stem to the leaf (Wildon et al. 1992). Blocking of phloem transport by chilling the cotyledonary petiole of wounded cotyledon did not stop transmission of electrical signal and did not inhibit PI activity in the stem and leaf. Cutting off the wounded cotyledon just after the damage so that the electrical signal had not enough time to reach the stem did not cause changes in the PI expression. Thus, the function of electrical signals propagating in plants was unambiguously demonstrated (Roberts 1992; Wildon et al. 1992; Thain and Wildon 1993). Later, more detailed studies resulted in the conclusion that other signaling processes could also lead to systemic gene expression (Stanković and Davies 1997; Rhodes at al. 1999). In the light of these results the participation of both electrical and hydraulic signals and chemical substances could be accepted in PIs induction after wounding.

According to the above presented results electrical potentials should be recognized as important, multifunctional signals occurring in plants. APs can initiate both non-specific and specific adaptational responses in plants. Plants belonging to different systematic groups respond to various stimuli coming from environment with movements, changes of gene expression, the level of respiration, transpiration, photosynthesis, stem growth and water uptake as well as with changes in activity of enzymes.

Regardless of which transmission routes the excitation of a plant chooses, it always induces changes in ion flow. This occurs due to opening ion channels in the membrane. It concerns not only plasmalemma but also the endomembranes as ER, and particularly the tonoplast. The vacuole is a reservoir of $\mathrm{Ca}^{2+}$ ions, which are the main second messenger in signalling. Therefore, it is very important to study the ion channels of the tonoplast and other endomembranes, their influence on generation of electrical potential and, in consequence, on physiological responses of plants subject to the action of pathogens, viruses or other kinds of stress.

There are different ways $\mathrm{Ca}^{2+}$ ions can participate in intracellular signalling:

1) $\mathrm{Ca}^{2+}$ influx to the cytoplasm after a stimulus, activates $\mathrm{Ca}^{2+}$-dependent $\mathrm{Cl}^{-}$channels and in consequence depolarization of the membrane spreads. 2) A stimulus opens $\mathrm{Cl}^{-}$ channels and depolarization follows which opens $\mathrm{Ca}^{2+}$ channels in the vacuole and $\mathrm{Ca}^{2+}$ concentration in cytoplasm increases. 3) A stimulus induces opening of cation channels and through them $\mathrm{Ca}^{2+}$ flow into the cytoplasm, which causes activation of $\mathrm{Cl}^{-}$channels depending on $\mathrm{Ca}^{2+}$ and depolarization and opening of vacuolar $\mathrm{Ca}^{2+}$ channels and $\mathrm{Ca}^{2+}$ concentration increase in the cytoplasm.
It is possible that plants can take advantage of various signals differing in mechanism of propagating and their action. They can be APs, VPs, chemical factors and signals resulting from hydraulic pressure change. Such a variety of mechanisms and ways of signal transmission „protects” plants in the environment.

\section{ACKNOWLEDGEMENTS}

This paper was financially supported by the State Committee for Scientific Researches (KBN).

\section{LITERATURE CITED}

ANTKOWIAK B., ENGELMANN W. 1995. Oscillations of apoplasmic $\mathrm{K}^{+}$and $\mathrm{H}^{+}$activities in Desmodium motorium (Houtt.) merril. Pulvini in relation to the membrane potential of motor cells i leaflet movements. Planta 196: 350-356.

BALDWIN I.T., PRESTON C.A. 1999. The eco-physiological complexity of plant responses to insect herbivores. Planta 208: pp 137-145.

BIRKENMEIER G.F., RYAN C.L. 1998. Wound signaling in tomato plants. Plant Physiol. 117: 687-693.

BOSE J.C., DAS G.P. 1925. Physiological and anatomical investigation on Mimosa pudica. Proc. Roy. Soc. B 98: 290-312.

BURDON-SANDERSON J.S. 1882. On the electromotive properties of the leaf of Dionaea in the excited and unexcited states. Phil. Trans. Soc. 173: 1-55.

CREELMAN R.A., MULLET J.E. 1997. Oligosaccharins, brassinolides, and jasmonates: nontraditional regulators of plant growth, development, and gene expression. Plant Cell 9: 1211$-1223$.

DAVIES E. 1987. Plant responses to wounding. In: The Biochemistry of Plants. Davies D.D. (ed.), Academic Press, New York 12: 243-264.

DAVIES E., VIAN A., VIAN C., STANKOVIĆ B. 1997. Rapid systemic up-regulation of genes after heat-wounding and electrical stimulation. APP 19: 571-576.

DAVIES E., ZAWADZKI T., WITTERS D. 1991. Electrical activity and signal transmission in plants: how do plants know? In: Plant Signalling, Plasma Membrane and Change of State. Penel C., Greppin H. (eds), Laboratory of Plant Physiology, University of Geneva 119-137.

DEMPSEY D.M.A., SHAH J. KLESSING D.F. 1999. Salicylic acid and disease resistance in plants. Criti. Rev. Plant Sciences 18: 547-575.

DZIUBIŃSKA H., PASZEWSKI A., TRĘBACZ K., ZAWADZKI T. 1983. Electrical activity of the liverwort Conocephalum conicum: The all-or-nothing law, strength-duration relation, refractory periods and intracellular potentials. Physiol. Plant. 57: 279-284.

DZIUBIŃSKA H., SZAREK I., TRĘBACZ K., ZAWADZKI T. 1999. Effects of local cutting on peroxidase activity in the liverwort Conocephalum conicum. Plant Peroxidase Newsletter 12: $3-8$.

DZIUBIŃSKA H., TRĘBACZ K., ZAWADZKI T. 1989. The effect of excitation on the rate of respiration in the liverwort $\mathrm{Co}$ nocephalum conicum. Physiol. Plant. 75: 417-423.

DZIUBIŃSKA H., TRĘBACZ K., ZAWADZKI T. 2001. Transmission route for action potentials and variation potentials in Helianthus annuus L. J. Plant Physiol. 158: 1167-1172.

EBEL J., MITHÖFER A. 1998. Early events in the elicitation of plant defence. Planta 206: 335-348.

ENYEDI A.J., YALPANI N., SILVERMAN P., RASKIN I. 1992. Signal molecules in systemic plant resistance to pathogens and pests. Cell 70: 879-886. 
ERMOLAYEVA E., HOHMEYER H., JOHANNES E., SANDERS D. 1996. Calcium-dependent membrane depolarization activated by phytochrome in the moss Physcomitrella patens. Planta, 199: 352-358.

ESCHRICH W., FROMM J., EVERT R.T. 1988. Transmission of electric signals in sieve tubes of zucchini plants. Botanica Acta 101: 327-331.

FARMER E.E., JOHNSON R.R., RYAN C.A. 1992. Regulation of expression of proteinase inhibitor genes by methyl jasmonate $\mathrm{i}$ jasmonic acid. Plant. Physiol. 98: 995-1002.

FARMER E.E., WEBER H.,VOLLENWEIDER S. 1998. Fatty acid signaling in Arabidopsis. Planta 206: 167-174.

FASANO J.M., MASSA G.D., GILROY S. 2002. Ionic signalling in plant responses to gravity and touch. J. Plant Growth Regulation 21: 71-88.

FILEK M., KOŚCIELNIAK J. 1997. The effect of wounding the roots by high temperature on the respiration rate of the shoot and propagation of electric signal in horse bean seedlings (Vicia faba L. minor). Plant Sci. 123: 39-46.

FISHER D.B., WU Y., KU M.S.B. 1992. Turnover of soluble proteins in the wheat sieve tube. Plant Physiol. 100: 1433-1441.

FROMM J. 1991. Control of phloem unloading by action potentials in Mimosa. Physiol. Plant. 83: 529-533.

FROMM J., BAUER T. 1994. Action potentials in maize sieve tubes changes phloem translocation. J. Exp. Bot. 45: 463-469.

FROMM J., ESCHRICH W. 1988a. Transport processes in stimulated and non-stimulated leaves of Mimosa pudica. I. The movement of ${ }^{14} \mathrm{C}$-labelled photoassimilates. Trees 2: 7-17.

FROMM J., ESCHRICH W. 1988b. Transport processes in stimulated and non-stimulated leaves of Mimosa pudica. II. Energesis and transmission of seismic stimulations. Trees 2: 18-24.

FROMM J., ESCHRICH W. 1993. Electric signals released from roots of willow (Salix viminalis L.) change transpiration and photosynthesis. J. Plant Physiol. 141: 673-680.

FROMM J., FEI H. 1998. Electrical signalling and gas exchange in maize plants of drying soil. Plant Science 132: 203-213.

FROMM J., HAJIREZAEI M., WILKE I. 1995. The biochemical response of electrical signalling in the reproductive system of Hibiscus plants. Plant Physiol. 109: 375-384.

GLAZEBROOK J. 1999. Genes controlling expression of defense responses in Arabidopsis. Curr. Opin. Plant Biol. 2: 280-286.

GRADMANN D. 1976. "Metabolic" action potentials in Acetabularia. J. Membrane Biol. 22: 23-45.

GREEN T.R., RYAN C.A. 1973. Wound-induced proteinase inhibitor in tomato leaves. Plant. Physiol. 51: 19-21.

GUNAR I.I., SINYUKHIN A.M. 1963. Functional significance of action currents affecting the gas exchange of higher plants. Fizioł. Rast. 10: 219-226.

HEJNOWICZ Z., PIJANOWSKI A., GŁĘBICKI K. 1986. An oscillatory component of propagated fluctuation electric potential in lupine shoot. Acta Soc. Bot. Pol. 55: 53-66.

HERDE O., CORTÉS H.P., WASTERNACK C., WILLMITZER L., FISAHIN J. 1999. Electric signaling and Pin2 gene expression on different abiotic stimuli depend on a distinct threshold level of endogenous abscisic acid in several abscisic acid-deficient tomato mutants. Plant Physiol. 119: 213-218.

HODICK D., SIEVERS A. 1988. The action potential of Dionaea muscipula Ellis. Planta 174: 8-18.

HOWE G.A., RYAN C.A. 1999. Suppressors of systemin signalling identify genes in the tomato wound response pathway. Genetics 153: 1411-1421

IIJIMA T., SIBAOKA T. 1981. Action potential in the trap-lobes of Aldrovanda vesiculosa. Plant Cell Physiol. 22: 1595-1601.

IIJIMA T., SIBAOKA T. 1982. Propagation of action potentials over the trap-lobes of Aldrovanda vesiculosa. Plant Cell Physiol. 23: 679-688.

IIJIMA T., SIBAOKA T. 1983. Movements of $\mathrm{K}^{+}$during shutting and opening of the trap-lobes in Aldrovanda vesiculosa. Plant Cell Physiol. 24: 51-60.
IIJIMA T., SIBAOKA T. 1985. Membrane potentials in excitable cells of Aldrovanda vesiculosa trap-lobes. Plant Cell Physiol. 26: 1-13.

ISHIWATARI Y., HONDA C., KAWASHIMA I., NAKAMURA S., HIRANO H., MORI S., FUJIWARA T., HAYASHI H., CHINO M. 1995. Tioredoxin is one of the major proteins in rice phloem sap. Planta 195: 456-463.

JACOBSON S.L. 1974. Effect of ionic environment on the response of the sensory hair of Venus-flytrap. Can. J. Bot. 52: 1293-1302.

KALININ V.A., OPRITOV V.A., KHUDYAKOV V.A. 1970 Formation of free radicals during propagation of an excitation wave along the conducting system of a higher plant. Fizjol. Rast. 17: 309-313.

KODA Y. 1997. Possible involvement of jasmonates in various morphogenic events. Physiol. Plant. 100: 639-646.

LABADY A., THOMAS D., SHVETSOVA T., VOLKOV A.G. 2002. Plant bioelectrochemistry: effect of CCCP on electrical signalling in soybean. Bioelctrochemistry 57: 47-53.

LAWTON K.A., POTTER S.L., UKNES S., RYALS J. 1994. Acquired resistance signal transduction in Arabidopsis is ethylene independent. Plant Cell 6: 581-588.

LEÓN J., ROJO E., SÁNCHEZ-SERRANO J.J. 2001. Wound signalling in plants. J. Exp. Bot. 52: 1-9.

MALONE M. 1992. Kinetics of wound-induced hydraulic signals and variation potentials in wheat seedings. Planta 187: 505-510 .

MALONE M., ALARCON J.-J. 1995. Only xylem-borne factors can account for systemic wound signalling in the tomato plant. Planta 196: 740-746.

MALONE M., ALARCON J.-J., PALUMBO L. 1994. An hydraulic interpretation of rapid, long-distance wound signalling in the tomato. Planta 193: 181-185.

MALONE M., STANKOVIĆ B. 1991. Surface potentials and hydraulic signals in wheat leaves following localized wounding by heat. Plant, Cell Environ. 14: 431-436.

MANCUSO S. 1999. Hydraulic and electrical transmission of wound-induced signals in Vitis vinifera. Aust. J. Plant Physiol. 26: $55-61$

MAUCH F., MEEHL J.B., STAEHELIN L.A. 1992. Ethylene-induced chitinase and $\beta-1,3$-glucanase accumulate specifically in the lower epidermis and along vascular strands of bean leaves. Planta 186: 367-375.

MULHERN J.E., STAVISH B.M., WITKOWSKI S.L., SHORELE W.C., SHIGO A.L. 1981. Voltage changes alonge geranium petioles after leaf blade excision. J. Exp. Bot. 32: 573-579 .

NARVÁEZ-VÁSQUEZ J., PEARCE G., OROZCO-CARDENAS M.L., FRANCESCHI V.R., RYAN C.A. 1995. Autoradiographic and biochemical evidence for the systemic translocation of systemin in tomato plants. Planta 195: 593-600.

OLSSON S., HANSSON B.S. 1995. Action potential - like activity found in fungal mycelia is sensitive to stimulation. Naturwissenschaften 82: 30-31.

OPRITOV V.A., RETIVIN V.G. 1982. On the mechanism of excitation in higher plants. Fizjol. Rast. 29: 915-924.

PASZEWSKI A., DZIUBIŃSKA H., TRĘBACZ K., ZAWADZKI T. 1982. Electrical activity of the liverwort Conocephalum conicum: Method of investigation and general characteristics of excitation. Physiol. Plant. 54: 83-87.

PASZEWSKI A., ZAWADZKI T. 1974. Action potentials in $\mathrm{Lu}$ pinus angustifolius L. shoots. II. Determination of the strength-duration relation and the all-or-nothing law. J. Exp. Bot. 25: 1097-1103.

PASZEWSKI A., ZAWADZKI T. 1976a. Action potentials in Lupinus angustifolius L. shoots. III Determination of the refractory periods. J. Exp. Bot. 27: 369-374.

PASZEWSKI A., ZAWADZKI T. 1976b. Action potentials in Lupinus angustifolius L. shoots. IV. Application of thermal 
stimuli and investigation on the conduction pathways of the excitation. J. Exp. Bot. 27: 859-863.

PENNINCKX I.A.M.A., THOMMA B.P.H.J., BUCHALA A., MÉTRAUX J-P., BROEKAERT W.F. 1998. Concomitant activation of jasmonate and ethylene response pathways is required for induction of a plant defensin gene in Arabidopsis. Plant Cell 10: 2103-2113.

PICKARD W.F., MINCHIN P.E.H. 1990. The transient inhibition of phloem translocation in Phaseolus vulgaris by abrup temperature drops, vibration and electric shock. J. Exp. Bot. 41: 1361-1369.

PICKARD W.F., MINCHIN P.E.H. 1992. The electroshock-induced inhibition of phloem translocation. J. Exp. Bot. 43: 409-417.

PYATYGIN S.S., OPRITOV V.A., ABRAMOVA N.N., VODENEEV V.A. 1999. Primary bioelectric response of higher plant cells to the combined action of stress factors. Russian J. Plant Physiol. 46: 530-536.

RETIVIN V.G., OPRITOV V.A. 1986. Analysis of electrochemical gradients of potential-determining ions in the cells of conducting tissues of pumpkin in resting and exciting states. Fizjol. Rast. 33: 447-458.

RETIVIN V.G., OPRITOV V.A., FEDULINA S.B. 1997. Generation of action potential induces preadaptation of Cucurbita реро L. stem tissues to freezing injury. Russian J. Plant Physiol. 44: 432-442.

RHODES J.D., THAIN J.F., WILDON D.C. 1996. The pathway for systemic electrical signal conduction in the wounded tomato plant. Planta 200: 50-57.

RHODES J.D., THAIN J.F., WILDON D.C. 1999. Evidence for physically distinct systemic signalling pathways in the wounded tomato plant. Annals of Botany 84: 109-116.

RICCA U. 1926. Transmission of stimuli in plants. Nature 117: 654-655.

ROBERTS K. 1992. Potential awareness of plants. Nature 360: 14-15.

ROBLIN G., BONNEMAIN J.-L. 1985. Propagation in Vicia faba stem of a potential variation induced by wounding. Plant Cell Physiol. 26: 1273-1283.

ROJO E., LEÓN J., SÁNCHEZ-SERRANO J.J. 1999. Cross-talk between wound signalling pathways determines local versus systemic gene expression in Arabidopsis thaliana. Plant J. 20: $135-142$.

RYALS J.A., NEUENSCHWANDER U.H., WILLITS M.G., MOLINA A., STEINER H.-Y., HUNT M.D. 1996. Systemic acquired resistance. Plant Cell 8: 1809-1819.

RYAN C. 1974. Assay and biochemical properties of the proteinase inhibitor-inducing factor, a wound hormone. Plant Physiol. 54: 328-332.

SCHROEDER J.I. 1992. Ion channel regulation during stomatal movements. Phil. Trans. Roy. Soc. London B 338: 83-89.

SHIINA T., TAZAWA M. 1986. Action potentials in Luffa cylindrica and its effects on elongation growth. Plant Cell Physiol. 27: 1081-1089.

SHVETSOVA T., MWESIGWA J., VOLKOV A.G. 2001. Plant electrophysiology: FCCP induces action potentials and excitation waves in soybean. Plant Science 161: 901-909.

SHVETSOVA T., MWESIGWA J., LABADY A., KELLY S., THOMAS D., LEWIS K., VOLKOV A.G. 2002. Sobybean electrophysiology: effects of acid rain. Plant Science162: 723$-731$.

SIBAOKA T. 1954. Conduction mechanism of excitation in the petiole of Mimosa pudica. Sci. Rep. Tohoku Univ. 20: 72-88.

SIBAOKA T. 1962. Excitable cells in Mimosa. Science, N.Y. 137: 226.

SIBAOKA T. 1966. Action potentials in plant organs. Nervous and hormonal mechanisms of integrations. Symposia of the Society for Experimental Biology 20: 49-73.

SIBAOKA T. 1969. Physiology of rapid movements in higher plants. An. Rev. Plant Physiol. 20: 165-184.
SIBAOKA T. 1973. Transmission of action potentials in Biophytum. Bot. Mag. Tokyo 86: 51-61.

SIBAOKA T. 1979. Action potentials and rapid plant movements. In: Plant Groeth Substances, (ed.) Skoog F., Springer-Verlag, Berlin, Heidelberg, 462-469.

SIBAOKA T., TABATA T. 1981. Electronic coupling between adjacent internodal cells in Chara braunii: Transmission of action potentials beyond the node. Plant Cell Physiol. 22: 397-411.

SINYUKHIN A.M. 1973. Functional activity of the action potential of Pteropsida and Musci. Biofizika 18: 477-483.

SINYUKHIN A.M., BRITIKOV E.A. 1967. Generation of potentials in the pistils of Incarvillea and Lily in connection with the movement of the stigma and pollination. Fizjol. Rast. 14: 463$-476$

SINYUKHIN A.M., GORCHAKOV V.V. 1968. Role of stem conducting bundes in long distance transmission of stimulation by means of bioelectric pulses. Fizjol. Rast. 15: 477-487.

SPALDING E.P., COSGROVE D.J. 1993. Influence of electrolytes on growth, phototropism, nutation and surface potential in etiolated cucumber seedlings. Plant, Cell Environ. 16: 445-451 .

SPANJERS A.W. 1981. Bioelectric potential changes in the style of Lilium longiflorum Thumb after self- and cross-pollination of the stigma. Planta 153: 1-5.

STANKOVIĆ B., DAVIES E. 1996. Both action potentials and variation potentials induce proteinase inhibitor gens expression in tomato. FEBS Letters 390: 275-279.

STANKOVIĆ B., DAVIES E. 1997. Intracellular communication in plants: electrical stimulation of proteinase inhibitor gene expression in tomato. Planta 202: 402-406.

STANKOVIĆ B., DAVIES E. 1998. The wound response in tomato involves rapid growth and electrical responses, systemicaly up-regulated transcription of proteinase inhibitor and calmodulin and down-regulated translation. Plant Cell Physiol. 39: $268-274$

STANKOVIĆ B., ZAWADZKI T., DAVIES E. 1997. Characterization of variation potential in sunflower. Plant Physiol. 115: 1083-1088.

STANKOVIĆ B., WITTERS D., ZAWADZKI T., DAVIES E. 1998. Action potentials and variation potentials in sunflower: an analysis of their relationships and distinguishing characteristics. Physiol. Plant. 102: 611-618.

STICHER L., MAUCH-MANI B., MÉTRAUX J.P. 1997. Systemic acquired resistance. Annu. Rev. Phytopathol. 35: 235-270.

THAIN J.F., WILDON D.C. 1993. Electrical signalling in plants. In: Plant Signals in Interactions with Other Organisms, J. Schultz, I. Raskin (eds). American Society of Plant Physiologists 102-115.

TRĘBACZ K., TARNECKI R., ZAWADZKI T. 1989. Characteristics of the light induced generator potentials in the liverwort Conocephalum conicum. Physiol. Plant. 75: 20-23.

VAN SAMBEEK J.W., PICKARD B.G. 1976. Mediation of rapid electrical, metabolic, transpirational, and photosynthetic changes by factors released from wound. III. Measurement of $\mathrm{CO}_{2}$ and $\mathrm{H}_{2} \mathrm{O}$ flux. Can. J. Bot. 54: 2662-2671.

VIAN A., HENRY-VIAN C., SHANNITZ R., LEDOIGT G., FRACHISSE J.M., DESBIEZ M.O., JULIEN J.L. 1996. Is membrane potential involved in calmodulin gene expresion after external stimulation in plants. FEBS Lett. 380: 93-96.

VOLKOV A.G., COLLINS D.J., MWESIGWA J. 2000. Plant electrophysiology: pentachlorophenol induces fast action potentials in soybean. Plant Science 153: 185-190.

VOLKOV A.G., MWESIGWA J. 2001. Electrochemistry of soybean: effects of uncouplers, pollutants, and pesticides. J. Electroanal. Chem. 496: 153-157.

WANG K.L.-C., LI H., ECKER J.R. 2002. Ethylene biosynthesis and signalling networts. Plant Cell S131-S151.

WASTERNACK C., PARTHIER B. 1997. Jasmonate-signalled plant gene expression. Trends in Plant Science 2: 302-307. 
WILDON D.C., THAIN J.F., MINCHIN P.E.H., GUBB I.B., REILLY A.J., SKIPPER Y.D., DOHERTY H.M., O'DONNELL P.J., BOWLES D.J. 1992. Electrical signalling and systemic proteinase inhibitor induction in the wounded plant. Nature 360: 62-65.

WILDON D.C., DOHERTY H.M., EAGLES G., BOWLES D.J., THAIN J.F. 1989. Systemic responses arising from localized heat stimuli in tomato plants. Ann. Botany 64: 691-695.

WILLIAMS S.E., BENNET A.B. 1982. Leaf closure in the Venus flytrap: an acid growth response. Science 218: 1120-1122.

WILLIAMS S.E., PICKARD B.G. 1972. Receptor potentials and action potentials in Drosera tentacles. Planta 103: 193-221.
WILLIAMS S.E., SPANSWICK R. 1976. Propagation on the neuroid action potential of the carnivorous plant Drosera. J. Comp. Physiol. 108: 211-223.

ZAWADZKI T., DZIUBIŃSKA H., DAVIES E. 1995. Characteristics of action potentials generated spontaneously in Helianthus annuus. Physiol. Plant. 93: 291-297.

ZAWADZKI T., TRĘBACZ K. 1982. Action potentials in Lupinus angustifolius L. shoots. VI. Propagation of action potentials in the stem after the application of mechanical block. J. Exp. Bot. 33: 100-110.

ZAWADZKI T., TRĘBACZ K. 1985. Extra- and intracellular measurements of action potentials in liverwort Conocephalum conicum. Physiol. Plant. 64: 477-481.

\title{
DROGI TRANSMISJI SYGNAŁÓW I FIZJOLOGICZNA ROLA POTENCJAŁÓW ELEKTRYCZNYCH U ROŚLIN
}

\author{
STRESZCZENIE
}

Rośliny podlegają wpływom bodźców pochodzących ze środowiska. Są one od niego bardzo zależne i w przeciwieństwie do zwierząt nie są w stanie aktywnie uniknąć jego wpływom, często szkodliwym. Dlatego posiadając zdolność odbierania bodźców wykształciły też adekwatne odpowiedzi na nie. Reakcja taka może pojawić się tylko w obszarze działania bodźca, objąć część rośliny lub całą. W tym ostatnim przypadku jest to odpowiedź systemiczna. Reakcja rośliny wyrażona jest różną siłą i szybkością i rodzajem odpowiedzi. Powstaje pytanie o naturę sygnału niosącego informacje o bodźcu, drogi jego rozprzestrzeniania się i mechanizmu transmisji. Wyróżnia się trzy koncepcje transmisji pobudzenia: 1) rozchodzenie się czynników chemicznych powstałych w miejscu działania bodźca z prądem soku floemowego (lub poprzez atmosferę jeśli są to substancje lotne) do innych części rośliny, 2) bardzo szybka transmisja ksylemem fali ciśnienia hydraulicznego powstałego po uszkodzeniu rośliny. Łącząc hipotezę „hydrauliczną” $\mathrm{z}$ „,chemiczną” powstaje koncepcja hydraulicznej dyspersji. Zakłada ona, że substancje chemiczne powstałe po zranieniu mogą bardzo szybko przemieszczać się po całej roślinie z falą zmian ciśnienia hydraulicznego, 3) bodziec wywołuje zmianę potencjału o charakterze czynnościowym (action potential AP) a jego transmisja, odbywająca się na zasadzie obwodów lokalnych od komórki do komórki, może wystąpić wzdłuż całej rośliny, jej organu lub wyspecjalizowanej tkanki. Po silnych, uszkadzających bodźcach mogą pojawić się variation potentials (VPs), których natura różni się od APs. Postuluje się, że transmisja VP pojawia się dzięki hydraulicznej dyspersji zaś elektryczne zmiany są zjawiskiem wtórnym.

SŁOWA KLUCZOWE: potencjał czynnościowy, potencjał wariacyjny, transmisja sygnału, odpowiedź systemiczna. 